\title{
Asoka and Paul: transformations that led to effective transformational leadership
}

\author{
Cheryl Patton* \\ PhD student of Organizational Leadership, Eastern University, St Davids, PA, USA
}

\begin{abstract}
Asoka, the third Emperor of the Indian Mauryan Dynasty, was once a violent, acquisitive ruler. After spearheading an exceptionally bloody battle, he experienced a tremendous transformation. Leaving his brutal past behind him, Asoka reverted to a life of compassion and peace. As he promoted Buddhist principles, his own transformation led to the transformation of his many followers. Asoka became a magnanimous historical leader who is recognized for Buddhism's transition from a sect to a world religion. Paul, the Apostle, too, is acknowledged for his effective evangelization of his beliefs. He is known by many as the second founder of Christianity, by others as the actual founder. Paul's Christianity was a result of a profound personal transformation that was experienced on the road to Damascus, Syria. At that time referred to as Saul, he was intent on destroying Christianity until he witnessed a vision that convinced him to convert. This conversion catalysed the transformation of followers throughout the Roman Empire and beyond, resulting in Christianity becoming a world religion. By examining the pair's actions before and after their personal transformations, as well as the subsequent results, applicability to contemporary leadership is gleaned.
\end{abstract}

Keywords: Asoka, Ashoka, Paul the Apostle, Saul of Tarsus, transformational leadership, charisma, personal transformation, Buddhism, Catholicism

\section{INTRODUCTION}

The transformational leader motivates followers to accomplish more than expected (Bass 1985, p. 20). The leader does so by expressing an attractive vision, role modeling, and persuading followers to collaborate in order to reach intended goals (Schuh et al. 2013, p. 630). Two charismatic followers of major religious figures played a transformational role in the rise of their faiths. Asoka, ${ }^{1}$ a follower of Buddha,${ }^{2}$ and Paul, a

\footnotetext{
* The author thanks Joy Smith, Jeff McLean (posthumously) and two anonymous reviewers at Leadership and the Humanities for their very helpful comments on earlier versions of this paper. She is also thankful to Dr. David Greenhalgh for leading her to transfer her thoughts into writing for this work.

1. Alternate spelling: Ashoka.

2. Some historians argue that Asoka did not specifically convert to the Buddhist faith (Jain and Jain 2003; Molloy 2009), though there is a plethora of evidence to the contrary (Chaurasia 2008; Dhammika 1993; Smith 1901 [2013]; Thapar 2012). Smith (1901 [2013]) is one of a few scholars who believe that Asoka did not merely convert to Buddhism but actually became a Buddhist monk.
} 
disciple of Jesus Christ, enriched their own faiths after personal transformations. In turn, they transformed others through successful leadership behaviors.

\section{ASOKA'S TRANSFORMATIONAL EXPERIENCE}

Accounts vary greatly regarding the life of Asoka, as much relies on oral tradition. Only in the 1800s were inscriptions credited to Asoka deciphered. Asoka ruled as the third Emperor of the Indian Mauryan Dynasty in the third century BCE, the dynasty originated with his grandfather, Chandragupta (Gombrich 1994, p. 1). He was Chandragupta's favorite grandson. That was no small honor as the legendary Asoka was said to have over 90 brothers and sisters (Kirby and Rich 1926, p. 579; Smith 1901 [2013], p. 15). Scholars differ greatly on Asoka's degree of cruelty in his early reign, ranging from savage, ruthless, and cruel (Allen 2012; Dhammika 1993; Selvanayagam 1992), killing at least one of his brothers in order to gain the throne $^{3}$ (Dhammika 1993; Hamblin and Peterson 2012; Thapar 2012), to one who 'while naturally mild and reasonable, did not lack force and severity when dealing with felons' (Kirby and Rich 1926, p. 586). However, one can safely declare that he had no qualms about killing people who wronged him or got in his way. Like his grandfather and his father, Bindusara, Asoka wished to continue to expand his territory. During his reign, Asoka 'began to look with covetous eyes upon Kalinga, an independent kingdom on the southeast' (ibid.). The decision was made; in $261 \mathrm{BC},{ }^{4}$ the Mauryan Empire would invade Kalinga, known today as Orissa (Damon 2000, p. 10). Though the exact size of Asoka's army is unknown, Chandragupta's forces consisted of approximately 600,000 infantry, 30,000 cavalry, ${ }^{5} 9,000$ elephants, and 9,000 chariots (Kirby and Rich 1926, p. 584). Asoka's forces were considered to be of similar size. Thousands of Oriya soldiers were killed on the banks of the Daya River during the Kalinga War (Nare 2011, p. 104). After witnessing the aftermath of the bloody Kalinga War, however, this once-acquisitive, ruthless ruler decided to lead his people under the Buddhist principles of non-violence and compassion (Allen 2012).

\section{PAUL'S TRANSFORMATION}

Paul the Apostle was known at one time as Saul, a Pharisaic Jew. Saul grew up in Tarsus, the capital city of Cilicia in southeast Asia Minor (Royse 1904, p. 144). A member of a strict sect of Pharasaism, Saul received his early religious education from his conservative Hebrew parents; when he reached the age of twelve or thirteen he went to Jerusalem to learn from one of the most respected Rabbis of his time, Gamaliel (Howson 1909, p. 4). As such, Saul was 'taught according to the perfect manner of the law

3. The Mahavamsa places the number involved in the fratricide at ninety-nine. Buddhist sources, in an attempt to magnify the conversion, greatly exaggerate the young Asoka's brutality. Those stories tell of an Asoka who, when he learned that women of his harem called him unsightly, had all five hundred burned to death, resulting in the moniker, Candasoka, or Cruel Asoka (Thapar 2012, pp. 34-36).

4. The year varies according to literature. Draper (1995) notes that the War occurred around 256 BC.

5. Draper (1995) marks the number of Asoka's cavalry at 130,000. 
of the fathers' (ibid., p. 4). When this zealous Pharisee witnessed those he regarded as heretics promoting beliefs that clashed with the law and tradition of his forefathers, he violently tried to destroy their work. These heretics were Christians, who believed that Jesus Christ was the Messiah, the Son of God, raised from the dead after crucifixion. The fact that Jesus was crucified led Saul to believe that there was no possibility that this man was the Messiah. The law clearly stated that this man must be cursed, 'he who is hanged is accursed of God'6 (New King James Version, Deut. 21:23). Saul's hermeneutical understanding of the passage convinced him that Jesus, a man who died while hanging on a cross, was not the Messiah (Awwad 2011, p. 7). Saul was 'more exceedingly zealous of the traditions' of his ancestors (Gal. 1:14) and so put it upon himself to prevent others from straying from Jewish tradition. ${ }^{7}$ Acts 3:8 reveals 'he made havoc of the church, entering every house, and dragging off men and women, committing them to prison.' Intent on completing what he thought was God's work, extinguishing Christianity through cruel persecution was Saul's major focus (Phil. 3:6). That is, until one day as he was heading north from Jerusalem on his way to Damascus, Syria:

Then Saul, still breathing threats and murder against the disciples of the Lord, went to the high priest and asked letters from him to the synagogues of Damascus, so that if he found any who were of the Way, whether men or women, he might bring them bound to Jerusalem.

As he journeyed he came near Damascus, and suddenly a light shone around him from heaven. Then he fell to the ground, and heard a voice saying to him,

'Saul, Saul, why are you persecuting Me?'

And he said, 'Who are You, Lord?'

Then the Lord said, 'I am Jesus, whom you are persecuting. It is hard for you to kick against the goads.'

So he, trembling and astonished, said, 'Lord, what do You want me to do?'Then the Lord said to him, 'Arise and go into the city, and you will be told what you must do.'

And the men who journeyed with him stood speechless, hearing a voice but seeing no one. Then Saul arose from the ground, and when his eyes were opened he saw no one. But they led him by the hand and brought him into Damascus. And he was three days without sight, and neither ate nor drank. (Acts 9:1-9)

This vision ${ }^{8}$ resulted in a complete transformation in Saul, who now took on the name Paul (Acts 13:9) and was baptized a Christian (Acts 9:18).

\section{ASOKA'S LEADERSHIP POST-TRANSFORMATION}

After the Kalinga War, Asoka dedicated much time and energy to promoting Dhamma, ${ }^{9}$ a Buddhist term originating from the root 'dham', which means 'to uphold

6. After his conversion, Paul addresses this passage in Galatians 3:13, noting 'Christ has redeemed us from the curse of the law, having become a curse for us.'.

7. Scholars believe Saul was a Shammaite Pharisee, the strictest sect of Jew. During the reign of King Herod from 36-4 BC, a split occurred within Pharisaism. Followers were divided between the strict teachings of Shammai and the more tolerant teachings of Hillel. A Shammaite was a 'hard-line Pharisee - what we today would call a militant right-winger' (Wright 1997, p. 26).

8. Scholars interpret this vision in numerous ways. Some propose that Saul was overcome by guilt, which led to hallucinations (Ludemann 2002). Others speculate that Saul was struck by lightning (Bullock 1994), temporal lobe epilepsy (Landsborough 1987), or a near-death experience (Morse 2009).

9. Dhamma is the Prakrit version of the Sanskrit word, dharma (Thapar 2012). 
and/or support,' among his followers (Asoka's Fourteen Rock Edicts, 4; Plamintr 2000). The Dhamma practice encourages charitable acts to be performed to avoid Dukkha, or sorrow (Plamintr 2000). The Emperor, otherwise known as Devanampiya Piyadasi, meaning 'Beloved of the Gods, He Who Looks on with Affection,' inscribed monuments, pillars, cave walls, and rock formations with his socio-religious edicts intended to catalyse positive changes throughout India ${ }^{10}$ (Dhammika 1993; Hamblin and Peterson 2012). His choice of writing in stone was purposeful; he desired his descendants to 'act in conformity' with the Dhamma (Fourteen Pillar Edicts, 5).

This once-cruel Mauryan ruler openly regretted the devastation that occurred at Kalinga.

Beloved of the Gods, King Piyadasi, conquered the Kalingas eight years after his coronation. One hundred and fifty thousand were deported, one hundred thousand were killed and many more died (from other causes). After the Kalingas had been conquered, Beloved of the Gods came to feel a strong inclination towards the Dhamma, a love for the Dhamma and for instruction in Dhamma. Now Beloved of the Gods feels deep remorse for having conquered the Kalingas. (Fourteen Rock Edicts, 13)

His messages revealed that he wished for his sons and grandsons to foregothe pursuit of conquests, if possible. Alternatively, they should only conquest 'with forbearance and light punishment' or by Dhamma alone (Fourteen Rock Edicts, 13).

Asoka was fully invested in fulfilling the highest needs of his people, those which result in 'happiness in this world and the next' (Seven Pillar Edicts, 1). This type of leadership behavior aligns with the Bolman and Deal (2013) human resource frame, which assumes that 'organizations exist to serve human needs rather than the converse' (p. 117). Specific practices of human resource strategies include 'build[ing] systems and practices to implement the philosophy,' 'invest[ing] in learning,' and being 'explicit ... about the organization's diversity philosophy' (ibid., p. 140). Asoka accomplishes these three goals. The inscriptions on pillars, rocks, and cave walls became the marketing tools for the promotion of 'kindness, generosity, truthfulness, purity, gentleness, and goodness' (Seven Pillar Edicts, 7). These inscriptions aided in the education of his followers, as did the instructions from the Rahhukas, who were ordered by Asoka to explain the tenets of the Dhamma in detail (Seven Pillar Edicts, 7). The Mauryan leader also expressed the need for diversity amongst his subjects. Though he was a staunch Buddhist, he was tolerant of other religions, asserting that 'all of them desire self-control and purity of heart' (Fourteen Rock Edicts, 7). So great was his inclusivism that it was his hope that 'all should be well-learned in the good doctrines of other religions' (Fourteen Rock Edicts, 12).

Asoka clearly fit the depiction of the transformational leader. The attractive vision of delight in the present life and beyond, his dramatic change and apparent sincerity and dedication to the cause sparked interest in his subjects. A transformational leader tends to trigger a difference in 'followers' ways of thinking, values, goals and standards' (Popper 2012, p. 31). The Emperor's social marketing campaign advised his followers to respect others, be generous, not kill, and be moderate in spending and saving (Fourteen Rock Edicts, 3). He postulated 'practicing the Dhamma cannot be done

10. James Prinsep deciphered Asoka's brahmi script in 1837, allowing scholars to re-discover this Mauryan leader. In subsequent decades, many of the edicts were discovered and a biography of Asoka began to unveil (Dhammika 1993). In Delhi, one can view versions of Asoka's edicts in Bahapur, South Delhi, on the Delhi Ridge, near the University of Delhi, and at Firoz Shah Kotla (Singh 2006, p. 120). 
by one who is devoid of virtue and therefore its promotion and growth is commendable' (ibid., 4). Asoka's motivational edicts successfully raised his followers to a higher ethical level; he was an accomplished driver of social change. Asoka referred to his inscriptions as 'rescripts on morality' (Chakrabarti 1995, p. 196). Leadership that 'raises the level of human conduct and ethical aspirations of both leader and led' transforms both in the process (Burns 1978, p. 20). Scholars note that Asoka continued to grow in his Buddhist fervor. This is further illustrated in the first Minor Rock Edict in which Asoka notes his spiritual growth and continues to encourage his followers. The Emperor proclaimed that he repeated the following communiqué two hundred and fifty-six times 'while on tour' (Dhammika 1993; Minor Edict, 1):

It is now more than two and a half years since I became a lay-disciple, but until now I have not been very zealous. But now that I have visited the Sangha ${ }^{11}$ for more than a year, I have become very zealous. Now the people in India who have not associated with the gods do so. This is the result of zeal and it is not just the great who can do this. Even the humble, if they are zealous, can attain heaven. And this proclamation has been made with this aim.

Role-modeling behavior is indicative of the transformational leader; Asoka aspires that the zeal he obtained from following the tenets of the Dhamma will be replicated by the masses. In guiding twenty-first century leaders, Rost (1993) reveals that '[r]eal transformation involves active people, engaging in influence relationships based on persuasion, intending real changes to happen, and insisting that those changes reflect their mutual purpose.' The fifth of the Fourteen Rock Edicts addresses the Dhamma Mahamatras, officers who Asoka appointed to 'practice and spread' the Dhamma (Thapar 2012). These officials worked 'among the Greeks, the Kambojas, the Gandharas, the Rastrikas, the Pitinikas and other peoples on the western borders' (Dhammika 1993; Fourteen Rock Edicts, 5). Scholars assume the Dhamma Mahamatras visited areas within and on the outskirts of the empire (Thapar 2012). Asoka made pilgrimages to Bodh Gaya ${ }^{12}$ and Lumbini, the latter being the birthplace of Buddha. Here, he erected a pillar and stupa ${ }^{13}$ to commemorate the journey (Dhammika 1993). In the seventh of the Seven Pillar Edicts, written 27 years after his coronation, Asoka remarked of his success in his role-modeling behavior, 'Whatever good deeds have been done by me, those the people accept and those they follow.'

Asoka referred to himself as a parental figure: 'All men are my children' (Kalinga Rock Edicts, 2). Popper (2012) implies that the psychological effect of the association of the parental image with the leader addresses the need for security in the follower. Asoka's repeated declarations of concern for his people allayed internal fears in the empire, resulting in tremendously successful leadership. H.G. Wells (1922, p. 165) called him the 'greatest of kings,' noting that Asoka's 'reign for eight-and-twenty years was one of the brightest interludes in the troubled history of mankind' (ibid., p. 163).

Another successful leadership tactic that Asoka employed was his readiness 'to hear complaints at all times and in all places' (Smith 1901 [2013], p. 30). Shenhar (1993) states that an open-door policy builds trust, encourages open communication, and

11. Sangha, or samgha is a Buddhist Order of Monks (Smith 1901 [2013]).

12. Bodh Gaya is the site where Gautama Siddhartha received enlightenment: the foundation of Buddhism (Myer 1958).

13. A stupa is often a dome-shaped mound, which serves as an object of veneration. Early Buddhist stupas contained relics of the Buddha, the historical beginning of the purpose of adoration (Singh 2006, p. 448). 
increases motivation. In the sixth of his Fourteen Rock Edicts, Asoka notes that 'in the past, state business was not transacted nor were reports delivered to the king at all hours.' Yet he reminds his people that he is always available to them, willing to attend to the welfare of the followers. Undoubtedly, this support was greatly appreciated by his followers.

Another key element in Asoka's transformational leadership style is that of persuasion. Within the Seven Pillar Edicts, Asoka reflects, 'The progress among the people through Dhamma has been done by two means, by Dhamma regulations and by persuasion.' Of the two, he credits persuasion as a more effective measure than laws: 'it is by persuasion that progress among the people through Dhamma has had a greater effect in respect of harmlessness to living beings and non-killing of living beings.'

\section{PAUL'S LEADERSHIP POST-TRANSFORMATION}

Paul was completely filled with zeal in spreading the vision of the kingdom of God, since his ontological change took place. He immediately went to work in proclaiming the Gospel (Good News) he had tried to dispel in the past. The Good News entailed the crucifixion of Christ being the victory over sin and death for followers (Wright 1997, p. 48). Paul thought of his transformation not as a change in faiths, but as a revelation of God's plan for the salvation of Israel (Sheler 1999).

Paul set out to spread the Good News to far-reaching areas. He formed networks and acted as a mentor to his traveling companions. It was during his first missionary journey (see Figure 1) that he began to be referred to as Paul instead of Saul. Paul left the familiarity of Hellenistic Antioch of Syria to the pagan, Roman-led Cyprus (Davis 2012). He and his traveling companions, Barnabas and Mark, continued the journey north into mainland Asia, which is present-day Turkey. In Pamphylia, Paul and Barnabas ventured to Pisidian Antioch (Acts 13:13-14) where Paul delivered his first recorded address (Acts 13:16-47). They were soon expelled, and visited Iconium, Lystra, and Derbe before returning to Antioch of Syria (Acts 14:1-27).

Silas accompanied Paul on his second missionary journey (Acts 15:40). Paul returned to previously established churches in Lystra and Derbe, exhibiting his continued support. The two moved on to Phrygia, Galatia, and into Europe, where they established churches in Macedonia (Philippi, Thessalonica, and Berea). The final leg of the journey was to Athens, Corinth, Ephesus, and Caesarea. Paul made a third mission, where he spent three years in Ephesus, and traveled to Greece through Macedonia.

During his travels, Paul faced persecution, even death. However, he continued to preach the Gospel, both verbally and through his writings. Ladkin (2010, p. 101) asserts that 'vision is an essential ingredient of most leadership theories.' Paul was successful, dedicated, and articulate in describing the vision of salvation through Christ. He ranks his vision greater than his life itself: 'But none of these things move me; nor do I count my life dear to myself, so that I may finish my race with joy, and the ministry which I received from the Lord Jesus, to testify to the gospel of the grace of God' (Acts 20:24).

Bass (1999) reveals that transformational leaders utilize their charisma - that is, their 'idealized influence' (p. 12) - to persuade their followers to look beyond self-interests. The modern-day definition of charisma actually stems from Paul's writings, in which he meant 'the gift of God's grace' (Potts 2009, p. 23). However, the contemporary 


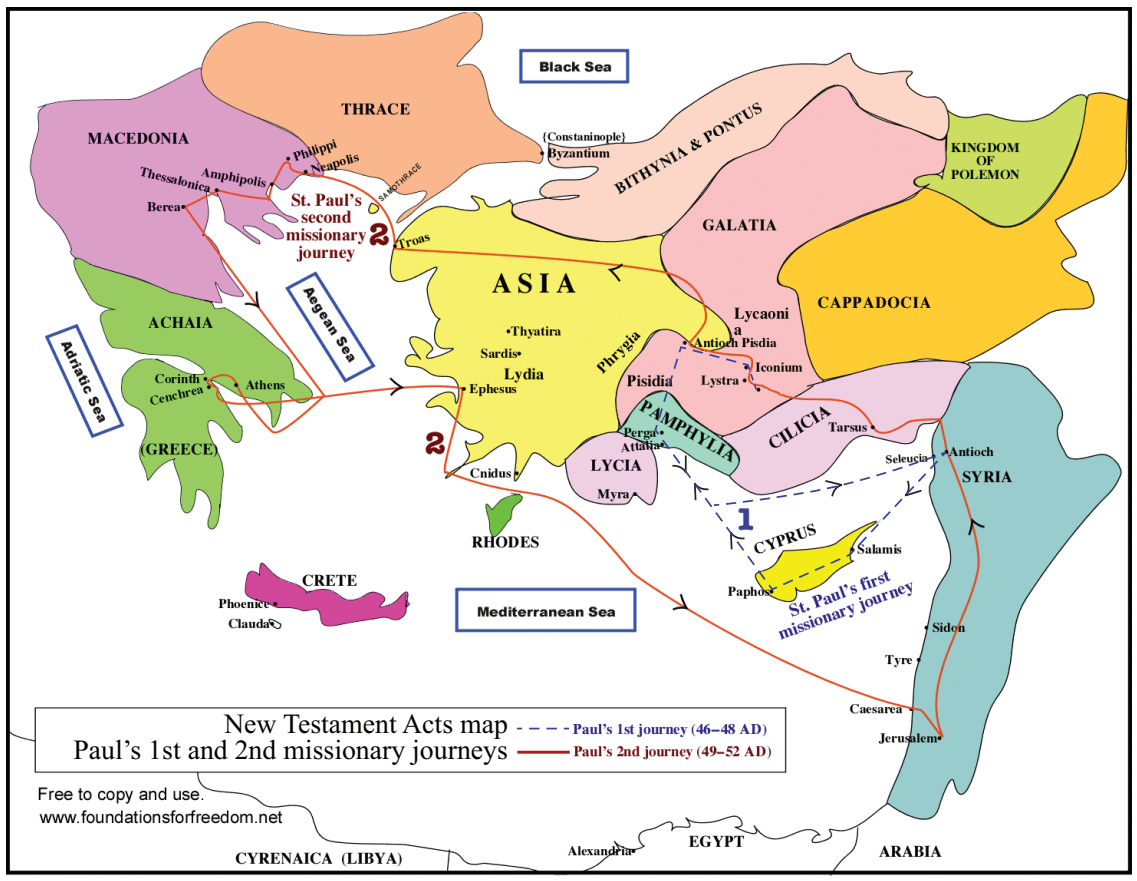

Source: Reprinted from Biblical Foundations for Freedom, by P.J. Bucknell (n.d.).

Figure 1 Map illustrating Paul's first (46-48 AD) and second (49-52 AD) missionary journeys

characterization of the term, derived from Max Weber, ${ }^{14}$ was evident in Paul's actions as well. People were drawn to his bold declarations and persistence through persecution. Immanuel Kant's theory of the sublime offers that followers are empowered by the idea that they can overcome an overwhelming circumstance. The charismatic leader will 'place the follower in a critical place of importance' (Ladkin 2010, p. 91). Those devotees whom Paul transformed were clearly warned of the critical nature of their followership: 'For I know this, that after my departure savage wolves will come in among you, not sparing the flock' (Acts 20:29).

Charismatic leadership is necessary when the status quo is threatened. Ladkin (2010, p. 84) notes: 'In much of the charismatic leadership literature, an often utilized behavior of charismatic leaders during such times is to communicate high expectations and confidence in their followers.' The following passage illustrates these behaviors as shown by Paul:

Therefore, my beloved, as you have always obeyed, not as in my presence only, but now much more in my absence, work out your own salvation with fear and trembling; for it is God who works in you both to will and to do for His good pleasure.

14. Weber's definition of charisma implies a character trait of leaders that sets them apart from others, attracting followers. Pierre Bourdieu and John Kotter are among the scholars who oppose this particular trait theory that proposes a 'mystical' or 'mysterious' characteristic 'inherent in a person' (Potts 2009, p. 3). 
Do all things without complaining and disputing, that you may become blameless and harmless, children of God without fault in the midst of a crooked and perverse generation, among whom you shine as lights in the world, holding fast the word of life, so that I may rejoice in the day of Christ that I have not run in vain or labored in vain.

Yes, and if I am being poured out as a drink offering on the sacrifice and service of your faith, I am glad and rejoice with you all. For the same reason you also be glad and rejoice with me. (Philippians 2:12-18)

Paul understood the importance of role-modeling, such a crucial aspect of transformational leadership. He encouraged his followers, 'Imitate me, just as I also imitate Christ' (1 Cor. 11:1). 'To model the way, leaders need to be clear about their own values and philosophy' (Northouse 2013, p. 198). Paul reminded them that he acted 'in simplicity and godly sincerity' toward them (2 Cor. 1:12). The transformational leader often takes on the role of coach or mentor (Bass and Steidlmeier 1999). Initially, Paul (Saul) began his mission as Barnabas's apprentice in evangelization, eventually assuming the responsibility of leader. Early in Luke's account in the Acts of the Apostles, Barnabas appeared first in the order of names, seemingly ordered in importance (Stenschke 2010). However, once he took on the name Paul in Paphos on the island of Cyprus, after he correctly announced Elymas would be stricken blind for opposing him, the order changes. From then on, Paul is the first mentioned (Acts 13:8-12). It is then that Paul does the mentoring. One such mentee was Timothy. Timothy's relationship with Paul began in Lystra where Paul carefully chose him for his stellar reputation and his potential for ministry work. In the mentoring process, Timothy is reminded of his value to Paul, is empowered for realization of his duties, and is periodically assigned challenging roles that help him grow in his work (Hoehl 2011). Paul passes on not only the spiritual teachings of faith, charity, diligence, and patience, but also the mission responsibilities of instruction, suffering, and behavior (Berding 2013). He exhibits trust in Timothy to properly administrate duties in his absence (1 Cor. 4:17). Paul expresses his mentoring and near-parental role in Philippians 2:19-23:

But I trust in the Lord Jesus to send Timothy to you shortly, that I also may be encouraged when I know your state. For I have no one like-minded, who will sincerely care for your state. For all seek their own, not the things which are of Christ Jesus. But you know his proven character, that as a son with his father he served with me in the gospel. Therefore I hope to send him at once, as soon as I see how it goes with me.

Another of Paul's mentees was Titus. In his second letter to the Corinthians, Paul references Titus on nine occasions. He writes that Titus serves as 'my partner and fellow worker concerning you' (2 Cor. 8:23). Like Timothy, Paul entrusted great responsibilities to Titus. Paul left him at Crete to finish the work that was started there; that he 'should set in order the things that are lacking, and appoint elders in every city' (Titus 1:5) and to 'remind them to be subject to rulers and authorities, to obey, to be ready for every good work' (Titus 3:1).

\section{OUTCOMES OF EVANGELIZATION EFFORTS}

As a result of the successful leadership skills of Asoka and Paul, Buddhism and Christianity became world religions (Chaurasia 2008). Smith (1901 [2013], pp. 21) asserts that Asoka's propagation of the Buddhist faith by dispatching missionaries to Ceylon (now Sri Lanka), Mysore (southern India), Bombay's coast, Mahratta country (central 
and western India), Pegu (now Bago), and 'to the mountaineers of the Himalayas and Kashmir,' transformed Buddhism from a regional sect to a world religion. Hirikawa (1990) specifically mentions Asoka's missionaries evangelizing in Macedonia, Egypt, and Syria. Asoka's own life transformation created a rippling effect, spreading Buddhism throughout India. Asoka successfully employed the aspects of the transformational leader to become one of the most magnanimous rulers of the Indian subcontinent (Dhammika 1993).

Paul has been referred to as "the most important figure in primitive Christianity and in the Church in general' (Ludemann 2002, p. 10) and 'perhaps the greatest Christian missionary and theologian who ever lived' (Whittington et al. 2005). Many scholars assert that he is the individual most responsible not only for the spread of Christianity throughout the Roman Empire, but also for it becoming a world religion (Ehrman 2004; Whittington et al. 2005). While often called the second founder of Christianity, some scholars, including Tabor (2012), posit that Paul should be considered the founder of Christianity as it is known today, 'rather than Jesus and his original Apostles' (p. 6). Bruce (1977) eloquently summarizes Paul's transformational leadership qualities, stating that Paul is one of the few individuals "who leave their mark on their time, who mold their contemporaries, and exert an influence which stretches far into the future' (p. 462). Paul, compared to Jesus, 'exercised beyond all doubt the stronger ... influence' (Wrede, as cited in Dunn 1998, p. 3).

\section{APPLICATIONS TO CONTEMPORARY LEADERSHIP}

First, and possibly most important to bear in mind, Paul and Asoka were both unethical before they became wildly successful leaders. It was the complete dedication to ethical behavior that propelled their ability to persuade followers; '[u]nethical charismatic leaders are manipulators who pursue their own personal agendas' (Ciulla 2012, p. 528). The true transformational leaders are those that 'act on socialized, rather than personalized, bases of power' (ibid., p. 528). By caring for their followers and striving for the greater good, Asoka and Paul increased their transformational leadership abilities.

Asoka and Paul modeled the behaviors they requested of their followers. By giving subordinates clear behaviors to emulate, displaying confidence in their vision, and setting lofty expectations for themselves and their followers, they inspired and motivated others to pursue their vision (Antonakis 2012). While both men used force to attain their visions prior to conversion, they actually became greater leaders afterward, when persuasion was accomplished without force.

Furthermore, Paul and Asoka were leaders with vision who had the ability to transform those around them, and beyond. Asoka clearly defined his vision for his followers, not only orally but also via the written word. His edicts were written in language that was readily comprehended by all. Iteration was another technique he used to ensure comprehension of his vision (Dhammika 1993). Contemporary leaders must clearly define their vision for the organization as well, making sure that each member understands the direction of the company. Periodic reminders are warranted in order to keep followers on target.

Both leaders were quite zealous in their roles and paid much attention to their followers, without hovering over their shoulders. Modern-day leaders need to show concern and care for their subordinates, while being careful not to micromanage. Additionally, it is of the utmost importance for leaders to be aware of their followers, to consider the audience when leading. Asoka could have had his edicts written in the 
most eloquent prose. However, he realized his followers had a simple vocabulary and the edicts were written accordingly.

Finally, both men's leadership styles accomplished the higher levels of morality that Burns (1978) attributes to the transformational leader. The pair also exhibited a spiritual and value-based component in their leadership, which Ritscher (1986) advocates in the transformational leader. It would behoove contemporary leaders to aspire to this type of leadership, as executive greed and corporate scandals prove destructive to organizations.

\section{CONCLUSION}

Asoka and Paul, once violent men, each underwent a personal transformation that, in turn, led them to become transformational leaders. The results of these occurrences led to the men being credited for making their respective beliefs, which at that time were narrowly focused, into world religions. They accomplished this significant task through various dimensions of transformational leadership. Their tenacity in promoting their visions, role modeling, confidence, and attention to followers should be emulated in today's organizations that are in need of their own positive transformations.

\section{REFERENCES}

Allen, Charles (2012), Ashoka: The Search for India's Lost Emperor. London: Little, Brown.

Antonakis, J. (2012), 'Transformational and Charismatic Leadership,' in D.V. Day and J. Antonakis (eds), The Nature of Leadership, 2nd edn. Thousand Oaks, CA: Sage, pp. 256-288.

Awwad, Johnny (2011), 'From Saul to Paul: The Conversion of Paul the Apostle,' Theological Review, 32, 1-14.

Bass, Bernard M. (1985), Leadership and Performance Beyond Expectations. New York: Free Press.

Bass, Bernard M. (1999), 'Two Decades of Research and Development in Transformational Leadership,' European Journal of Work and Organizational Psychology, 8(1), 9-32.

Bass, Bernard M. and Paul Steidlmeier (1999), 'Ethics, Character, and Authentic Transformational Leadership Behavior,' Leadership Quarterly, 10(2), 181-217.

Berding, Kenneth (2013), 'At the Intersection of Mission and Spiritual Formation in the Letters of Paul,' Journal of Spiritual Formation and Soul Care, 6(1), 18-37.

Bolman, L.G. and T.E. Deal (2013), Reframing Organizations: Artistry, Choice and Leadership, 5 th edn. San Francisco, CA: Jossey-Bass.

Bruce, F.F. (1977), Paul: Apostle of the Heart Set Free. Grand Rapids, MI: William B. Eerdmans.

Bucknell, Paul J. (n.d.), 'Acts Map: Paul's First and Second Missionary Journeys,' Biblical Foundations for Freedom. Retrieved from http://www.foundationsforfreedom.net/References/ NT/Acts/Acts_Map_1-2_Journey.html.

Bullock, John D. (1994), 'Was Saint Paul Struck Blind and Converted by Lightning?' Survey of Ophthalmology, 39(2), 151-160.

Burns, James M. (1978), Leadership. New York: Harper Collins.

Chakrabarti, Dilip K. (1995), 'Buddhist Sites Across South Asia as Influenced by Political and Economic Forces,' World Archaeology, 27(2), 185-202.

Chaurasia, Radhi Shyam (2008), History of Ancient India: Earliest Times to 1200 A.D. New Delhi: Atlantic Publishers.

Ciulla, Joanne B. (2012), 'Ethics and Effectiveness,' in D.V. Day and J. Antonakis (eds), The Nature of Leadership, 2nd edn. Thousand Oaks, CA: Sage, pp. 508-540. 
Damon, D. (2000), 'His Sacred Majesty's Remorse,' Calliope, 10(5), 10-12.

Davis, Thomas W. (2012), 'Saint Paul on Cyprus: Archaeology and the Transformation of an Apostle,' Perspectives on Science and Christian Faith, 64(4), 230-241.

Dhammika, Ven S. (1993), The Edicts of King Asoka. Kandy, Sri Lanka: Buddhist Publication Society. Retrieved from http://www.cs.colostate.edu/ malaiya/ashoka.html.

Draper, Gerald (1995), 'The Contribution of the Emperor Asoka Maurya to the Development of the Humanitarian Ideal in Warfare,' International Review of the Red Cross, No 305.

Dunn, J.D. (1998), The Theology of Paul the Apostle. Grand Rapids, MI: William B. Eerdmans.

Ehrman, Bart (2004), 'Christianity Without Paul: What Would the Religion be Like if Apostle Paul Had Never Lived?' Beliefnet. Retrieved from http://www.beliefnet.com/Faiths/ Christianity/2004/04/Christianity-Without-Paul.aspx.

Gombrich, Richard (1994), 'Asoka - The Great Upsasaka,' in Anuradha Seneviratna (ed.), King Asoka and Buddhism. Kandy, Sri Lanka: Buddhist Publication Society, pp. 1-14. Retrieved from http://www.urbandharma.org/pdf/king_asoka.pdf.

Hamblin, William J. and Daniel Peterson (2012), 'Indian Ruler Sows Seeds of Buddhism,' The Deseret News, May 6. Record number: 765573699.

Hirakawa, Akira (1990), A History of Indian Buddhism: From Sakyamuni to Early Mahayana. Trans. Paul Groner. Delhi: Motilal Banarsidass.

Hoehl, Stacy E. (2011), 'The Mentor Relationship: An Exploration of Paul as Loving Mentor to Timothy and the Application of this Relationship to Contemporary Leadership Challenges,' Journal of Biblical Perspectives in Leadership, 3(2), 32-47.

Howson, J.S. (1909), Scenes from the Life of Saint Paul. London: The Religious Tract Society.

Jain, Duli Chandra and Sunita Jain (2003), 'Ashok - Emperor or Monk,' Jain Study Circular, July, 48-50.

Kirby, Gladys Burrell and Frank M. Rich (1926), 'Asoka: The Peerless Monarch of India,' The Open Court, 40(10), 577-595.

Ladkin, Donna (2010), Rethinking Leadership: A New Look at Leadership Questions. Cheltenham, UK and Northampton, MA: Edward Elgar.

Landsborough, D. (1987), 'St Paul and Temporal Lobe Epilepsy,' Journal of Neurology, Neurosurgery and Psychiatry, 50(6), 659-664.

Ludemann, Gerd (2002), Paul: The Founder of Christianity. Amherst, NY: Prometheus Books.

Molloy, Michael (2009), Experiencing the World's Religions: Tradition, Challenge, and Change, 5th revised edn. Boston, MA: McGraw Hill Higher Education.

Morse, Donald R. (2009), 'Did Paul have a NDE on the Road to Damascus?' Journal of Spirituality and Paranormal Studies, 32(1), 1-2.

Myer, Prudence R. (1958), 'The Great Temple at Bodh-Gaya,' The Art Bulletin, 40(4), 277-298.

Nare, Veena (2011), 'Jahanta Mahapatra's Relationship: A Prolonged Romantic Agony,' Rock Pebbles: A Peer-Reviewed International Literary Journal, 15(1), 103-107.

Northouse, Peter G. (2013), Leadership: Theory and Practice. Thousand Oaks, CA: Sage.

Plamintr, S. (2000), 'The Dhamma,' Buddhism Today. Retrieved from http://www.buddhismtoday. com/english/beg/012-dhamma.htm.

Popper, Micha (2012), Fact and Fantasy about Leadership. Cheltenham, UK and Northampton, MA: Edward Elgar.

Potts, John (2009), A History of Charisma. New York: Palgrave Macmillan.

Ritscher, J.A. (1986), 'Spiritual Leadership,' in J.A. Adams (ed.), Transforming Leadership. Alexandria, VA: Miles River Press, pp. 61-80.

Rost, Joseph C. (1993), Leadership for the Twenty-first Century. Westport, CT: Praeger.

Royse, Clarence D. (1904), 'The Psychology of Paul's Conversion,' American Journal of Religious Psychology and Education, 1(1), 143-154.

Schuh, Sebastian C., Xin-an Zhang, and Peng Lian (2013), 'For the Good or the Bad? Interactive Effects of Transformational Leadership with Moral and Authoritarian Leadership Behaviors,' Journal of Business Ethics, September, 629-640.

Selvanayagam, Israel (1992), 'Aśoka and Arjuna as Counterfigures Standing on the Field of Dharma: A Historical-Hermeneutical Perspective,' History of Religions, August, 58-75.

Sheler, Jeffrey L. (1999), 'Reassessing an Apostle,' U.S. News and World Report, 126(13), 52. 
144 Leadership and the Humanities, Vol. 3 No. 2

Shenhar, Aaron (1993), 'Keeping Management's Door Open: How to Establish an Open-Door Policy that Works,' Leadership and Organizational Development Journal, 14(2), 8-12.

Singh, Upinder (2006), 'A Tale of Two Pillars,' in Upinder Singh (ed.), Ancient History. Jor Bagh: New Delhi Social Science Press, pp. 119-122.

Smith, Vincent A. (1901 [2013]), Asoka, the Buddhist Emperor of India. London: Forgotten Books.

Stenschke, C.W. (2010), 'When the Second Man Takes the Lead: Reflections on Joseph Barnabas and Paul of Tarsus and Their Relationship in the New Testament,' Koers, 75(3), 503-525.

Tabor, J.D. (2012), Paul and Jesus: How the Apostle Transformed Christianity. New York: Simon \& Schuster.

Thapar, Romila (2012), Asoka and the Decline of the Mauryas, 3rd edn. New Delhi: Oxford University Press.

Wells, H.G. (1922), A Short History of the World. New York: Macmillan.

Whittington, J.L., Tricia M. Pitts, Woody V. Kageler, and Vicki L. Goodwin (2005), 'Legacy Leadership: The Leadership Wisdom of the Apostle Paul,' Leadership Quarterly, 16, 749-770.

Wright, Tom (1997), What St Paul Really Said. Oxford: Lion Publishing. 